\title{
Cancer of the Penis: Clinical Features and Therapeutic Modalities in Senegalese Hospitals
}

\author{
Amath Thiam, Alioune Sarr, Ousmane Sow ", Ndeye Aïssatou Bagayogo, Modou Ndiaye, \\ Babacar Sine, Cyrille Ze Ondo, Abdoulaye Ndiath, El Hadji Malick Diaw, Yaya Sow, Babacar Diao, \\ Alain Khassim Ndoye
}

Urology-Andrology Department, Aristide Le Dantec Hospital, Dakar, Senegal

Email address:

sowman87@yahoo.fr (O. Sow)

${ }^{*}$ Corresponding author

\section{To cite this article:}

Amath Thiam, Alioune Sarr, Ousmane Sow, Ndeye Aïssatou Bagayogo, Modou Ndiaye, Babacar Sine, Cyrille Ze Ondo, Abdoulaye Ndiath, El Hadji Malick Diaw, Yaya Sow, Babacar Diao, Alain Khassim Ndoye. Cancer of the Penis: Clinical Features and Therapeutic Modalities in Senegalese Hospitals. International Journal of Clinical Urology. Vol. 4, No. 2, 2020, pp. 81-84. doi: 10.11648/j.ijcu.20200402.21

Received: October 14, 2020; Accepted: October 23, 2020; Published: November 4, 2020

\begin{abstract}
Background: Penile cancer is a rare malignancy in Senegal. This rarity is probably related to the fact that circumcision, which has a protective effect, is a common practice in childhood. Some of the known risk factors include uncircumcised status, chronic inflammatory conditions, and a history of condyloma acuminata, smoking, and possibly human papillomavirus exposure. It is a pathology in adults with a maximum incidence after the age of 50. In our practice penile cancer is most often diagnosed at an advanced stage or only a radical and mutilating treatment may be proposed. Aims: To describe the clinical and therapeutic features of penis cancer in Senegal. Patients and methods: we carried out a retrospective, descriptive, bicentric study, collecting the records of patients with penis cancer in the Urology-Andrology department of the Aristide Le Dantec University hospital and the military hospital of Ouakam between January 2010 and December 2019. Results: fourteen cases of penile cancer were diagnosed. The mean age was 53.2 years with extremes of 29 and 84 years, the average consultation time was 21 months. All patients were circumcised in childhood. The tumor was limited to the glans in 2 cases and involved the entire penis in 5 cases. Six patients had bilateral inguinal adenopathies. The histological type was squamous cell carcinoma in all cases with a predominance of grade 2 ( 8 cases). Patients were classified as cT3 (7 cases), cT2 ( 5 cases), cT4 (1 case) and cT1 (1 case). Treatment consisted of partial amputation of the penis (5 cases), emasculation and perineal urethrostomy (4 cases) total amputation and perineal urethrostomy ( 2 cases). Three patients had refused total penis amputation. The average length of follow-up was 26 months (4 and 72 months), 3 lymph nodes recurrences and 2 local recurrences were observed. Two patients died among the operated patients. Conclusion: Cancer of the penis is rare in Senegal. The delay in diagnosis explains the frequency of advanced forms which can only be treated by radical surgery.
\end{abstract}

Keywords: Penile Cancer, Diagnostic Delay, Penile Amputation

\section{Introduction}

Cancer of the penis (CP) is a rare disease in Senegal. This rarity is probably related to the fact that circumcision, which has a protective effect, is a common practice in childhood [1] It is a pathology in adults with a maximum incidence after the age of 50 [2]. In our practice CP is most often diagnosed at an advanced stage or only a radical and mutilating treatment may be proposed [2]. The aim of this work was to report the epidemiological, clinical and therapeutic features of penile cancer in senegalese hospitals.

\section{Materials and Methods}

This is a retrospective, descriptive, bicentric study, collecting the files of patients with a CP in the UrologyAndrology department of the Aristide Le Dantec University hospital and the military hospital of Ouakam between January 2010 and December 2019. The parameters studied were the age at the time of diagnosis, the geographical origin of patients, the consultation time, the existence or not of risk 
factors or precancerous lesions, clinical characteristics (location, presence or not of adenopathies), histological characteristics (histological type, histological grade) the TNM 2009 classification, therapeutic modalities and followup after treatment.

\section{Results}

During the study period, $14 \mathrm{CP}$ cases were diagnosed. The mean age at diagnosis was 53.2 years ( 29 and 84 years). The average time of consultation was 21 months (5 and 48 months). All patients were circumcised in childhood and were all from rural areas. The clinical presentation was an ulcerated, budding lesion on the penis (Figure 1). The tumor was limited to the glans in 2 cases and involved the entire penis in 5 cases (figure 2). Six patients had bilateral inguinal adenopathies (Table 1). Biopsy of the lesion resulted in the diagnosis of invasive squamous cell carcinoma and the grade of tumor. There was a predominance of grade 2 (G2) with 8 cases (Table 1). Thoraco-abdomino-pelvic CT scan, carried out in all patients, showed pelvic lymph nodes (1 case) and pulmonary metastasis (1 case). Treatment consisted of partial amputation of the penis (5 cases), total amputation and perineal urethrostomy in 2 patients (Figure 3), emasculation and perineal urethrostomy in 4 patients (Figure 4). Three patients refused total penis amputation. Node dissection was performed in 3 patients and was positive in all cases. The average length of follow-up was 26 months (4 and 72 months). No local recurrence was observed among the 5 patients treated with partial amputation. One lymph node recurrence alone and 2 local and lymph node recurrences were observed in the patients treated by emasculation. Two patients had died. Table 1 summarises the clinical characteristics and therapeutic follow-up of the patients.

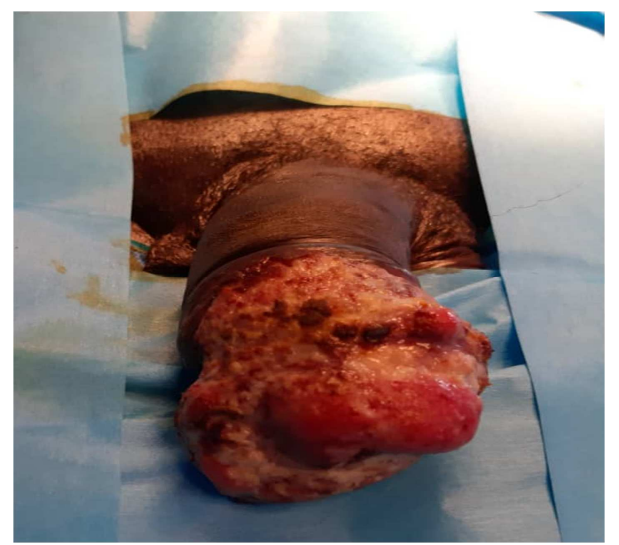

Figure 1. Budding tumor of the upper third of the penis.

Table 1. Summary table of clinical characteristics and therapeutic modality of patients.

\begin{tabular}{|c|c|c|c|c|c|c|c|}
\hline Patients & $\begin{array}{l}\text { Age } \\
\text { (years) }\end{array}$ & $\begin{array}{l}\text { Time to visit } \\
\text { (months) }\end{array}$ & Clinical aspects & Treatment & $\begin{array}{l}\text { Duration of } \\
\text { follow-up } \\
\text { (months) }\end{array}$ & Recurrence & Death \\
\hline 1 & 74 & 36 & $\begin{array}{l}\text { Tumor occupying the entire penis, bilateral } \\
\text { inguinal adenopathies cT3N2M0 G3 }\end{array}$ & $\begin{array}{l}\text { Total amputation }+ \\
\text { removal of lymph } \\
\text { nodes }\end{array}$ & 06 & Node recurrence & Yes \\
\hline 2 & 29 & 14 & Tumor limited to the glans, cT2N0M0 G2 & Partial Amputation & 36 & No & No \\
\hline 3 & 67 & 48 & $\begin{array}{l}\text { Tumor occupying the entire penis, bilateral } \\
\text { inguinal adenopathies cT3N2M0 G2 }\end{array}$ & Refusal of amputation & $\begin{array}{l}\text { lost from } \\
\text { sight }\end{array}$ & - & - \\
\hline 4 & 71 & 36 & $\begin{array}{l}\text { Tumor occupying the glans and } 1 / 3 \text { distal of the } \\
\text { penis: remaining length } 5 \mathrm{~cm} \text { cT2NOM0 G } 2\end{array}$ & Partial Amputation & 24 & No & No \\
\hline 5 & 63 & 24 & $\begin{array}{l}\text { Ulcerated and necrotic tumor. Remaining penis } \\
\text { length: } 2.5 \mathrm{~cm} \text { cT3N0M0 } 33\end{array}$ & Emasculation & 48 & No & No \\
\hline 6 & 34 & 05 & $\begin{array}{l}\text { Tumor occupying } 1 / 3 \text { distal of the penis: } \\
\text { remaining length } 6 \mathrm{~cm} \text { cT2N0M0 G2 }\end{array}$ & Partial Amputation & 72 & No & No \\
\hline 7 & 55 & 22 & $\begin{array}{l}\text { Tumor occupying the glans }+1 / 3 \text { distal of the } \\
\text { penis: remaining length }=5 \mathrm{~cm} \text { cT } 2 \mathrm{~N} 0 \mathrm{M} 0 \mathrm{G} 1\end{array}$ & Partial Amputation & 06 & Non & No \\
\hline 8 & 52 & 18 & $\begin{array}{l}\text { Tumor occupying the entire penis, bilateral } \\
\text { inguinal adenopathies cT3N2M0 G2 }\end{array}$ & Refusal of amputation & $\begin{array}{l}\text { lost from } \\
\text { sight }\end{array}$ & - & - \\
\hline 9 & 30 & 15 & Tumor limited to the glans, cT1N0M0 G1 & Partial Amputation & 24 & No & No \\
\hline 10 & 46 & 09 & $\begin{array}{l}\text { Tumor occupying the entire penis, the glans and } \\
1 / 3 \text { distal necrotic. inguinal and pelvic } \\
\text { adenopathies, cT3N3M0 G3 }\end{array}$ & Refusal of amputation & $\begin{array}{l}\text { lost from } \\
\text { sight }\end{array}$ & - & - \\
\hline 11 & 84 & 24 & $\begin{array}{l}\text { Tumor occupying the entire penis and scrotum, } \\
\text { mobile inguinal adenopathies, cT4N2M0 G2 }\end{array}$ & $\begin{array}{l}\text { Emasculation }+ \text { lymph } \\
\text { node cleansing }\end{array}$ & 04 & $\begin{array}{l}\text { Local and } \\
\text { ganglionic } \\
\text { recidivism }\end{array}$ & Yes \\
\hline 12 & 57 & 08 & $\begin{array}{l}\text { Tumor occupying the glans }+1 / 3 \text { medium of the } \\
\text { penis: remaining length } 2 \mathrm{~cm} \text { cT } 2 \mathrm{~N} 0 \mathrm{M} 0 \mathrm{G} 2\end{array}$ & Emasculation & 24 & No & No \\
\hline 13 & 53 & 24 & $\begin{array}{l}\text { Tumor occupying } 2 / 3 \text { of the penis } \\
\text { Remaining length } 3 \mathrm{~cm} \text { cT } 3 \mathrm{~N} 0 \mathrm{M} 0 \mathrm{G} 2\end{array}$ & Total Amputation & 36 & No & No \\
\hline 14 & 31 & 12 & $\begin{array}{l}\text { Tumor occupying the glans }+1 / 3 \text { distal of the } \\
\text { penis, inguinal adenopathies, pulmonary } \\
\text { metastases cT3N2M1 G3 }\end{array}$ & $\begin{array}{l}\text { Emasculation }+ \text { lymph } \\
\text { node removal }+ \\
\text { chemotherapy }\end{array}$ & 07 & $\begin{array}{l}\text { Local and } \\
\text { ganglionic } \\
\text { recidivism }\end{array}$ & $\begin{array}{l}\text { lost } \\
\text { from } \\
\text { sight }\end{array}$ \\
\hline
\end{tabular}




\section{Discussion}

$\mathrm{CP}$ are rare in Senegal, as Sow and Gueye [1, 2] have already reported. The incidence of this cancer varies according to geographical regions, customs and socioeconomic level. The highest incidence (up to 20\%) is found in African, Asian and Latin American countries compared to Western countries and the USA where it is less than 1\% [3]. The average age of 53 years is close to that of the African series; in the West, however, the average age appears to be higher [4-7]. Cancer of the penis is common in countries with low socio-economic levels, due to poor hygiene conditions [8]. The protective role of neonatal circumcision has been demonstrated by several authors [9-11]. Neonatal circumcision reduces the risk of penile cancer by 3 to 5 times by improving local hygiene and preventing chronic inflammation related to smegma accumulation $[3,12]$. The practice of circumcision in childhood is a widespread custom in Senegal, which may explain the low incidence of squamous cell carcinoma in this population of circumcised men. The involvement of human papillomavirus (HPV) infectious in the genesis of squamous cell carcinoma is known. In a meta-analysis of the results of 30 studies, HPV was confirmed in $47.9 \%$ of 1266 penile cancer samples [11]. On the clinical level, diagnostic delay is the rule in our study. This delay in diagnosis could be explained by the taboo surrounding any disease affecting the external genital organs. Some patients consult because of the pressure of the entourage, which is bothered by the nauseating odours of the lesions. All the patients in this study had an ulcerative budding tumor at the time of diagnosis, involving either the glans or the body of the penis. Similarly, Magoha in Kenya reported that $88 \%$ of the CP occupied the glans and the body of the penis and $12 \%$ were located in the foreskin [4]. In contrast, it appears that in the western series the lesions are confined to the glans or foreskin $[13,14]$. In our series all patients had squamous cell carcinoma of the penis. This is the most frequent histological type, other histological forms are rare. Nam et al [15] reported 2 cases of leiomyosarcoma, a penile location of a large B-cell non-Hodgkin's lymphoma was described in the series of Sow et al [9]. Squamous cell carcinoma of the penis has a slow progression, first locally, then secondarily regionally by invasion of the inguinal lymph nodes, and finally the pelvic lymph nodes. Metastatic localisations are infrequent and late $[15,16]$. The clinical presentation in our context necessarily lead to an immediate proposal for surgery to remove the penis (partial or total amputation) or for emasculation. This mutilating surgery is often refused by patients from the first announcement, hence the need for psychological assistance before and after the surgical procedure. Conservative therapies such as photodynamic treatment, YAG or $\mathrm{CO}_{2}$ laser excision, 5 fluorouracil topicality combined with biopsy and brachytherapy with iridium 192 wire make it possible to respect the anatomo-functional integrity of the penis and to offer a better quality of life with a significant risk of local recurrence [17]. However, these techniques are difficult to apply in our context where tumors are diagnosed late. As reported in other studies $[5,15,18]$, penis amputation was the most common therapeutic modality in this study ( 5 partial amputations and 6 total amputations). Radical excision surgery offers better local control of penile cancers in order to avoid recurrence $[5,13,15]$. The curative role of lymph node removal has been proven for all stages. The $\mathrm{N}+$ patients in this study ( 6 cases) were all received at a very advanced stage of the tumor. For N0 patients, lymph node removal was not systematically because of the significant morbidity that accompanies this procedure. Current data do not support the monitoring of these patients, Leijte et al as well as Sadeghi et al $[19,20]$ recommend the search for the sentinel node when there are no palpable nodes. Survival depends on the local stage, but especially on the lymph node stage, which is the main prognostic factor [17]. The two patients who died in this study all had inguinal lymphadenopathies at the time of diagnosis and lymph node recurrence after surgery. There is no consensus on the modalities and frequency of monitoring. Classically it is a clinical penile surveillance by local examination in case of partial amputation and lymph node areas.

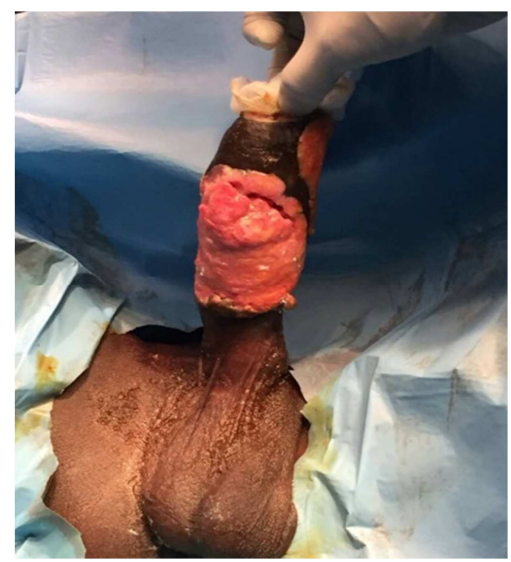

Figure 2. cT3NOMO penis tumor.

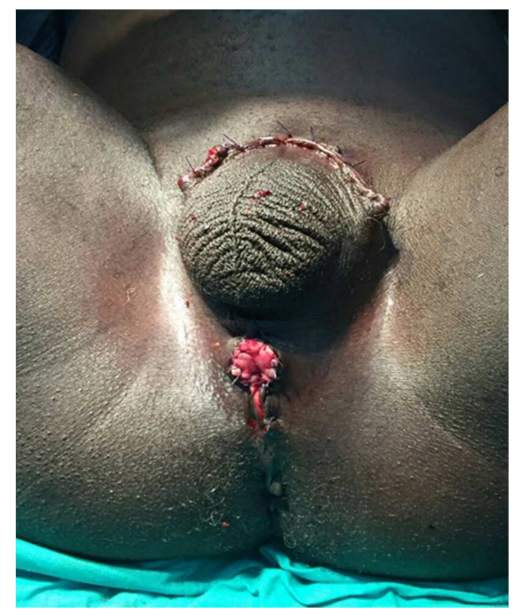

Figure 3. Total amputation + perineal meatostomy. 


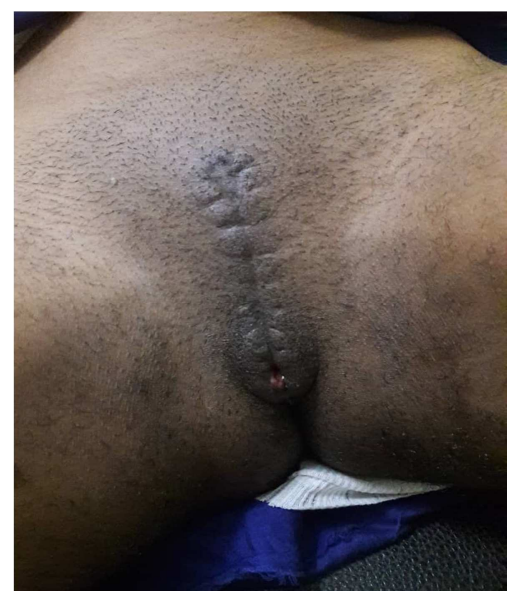

Figure 4. Appearance 1 year after emasculation and perineal urethrostomy.

\section{Conclusion}

$\mathrm{CP}$ is a rare tumor that mainly affects young adults in Senegal. The squamous cell carcinoma is the predominant type. The discovery is almost always late, in the advanced stage of cancer. Partial or total penectomy is most often indicated. However, body disfigurement and psychological consequences and social problems that can result from this sometimes explain therapeutic refusals. It is then necessary to raise awareness.

\section{Author's Contribution}

All authors have read and approved the final version of the manuscript.

\section{Conflicts of Interest}

The authors declare that they have no competing interests.

\section{References}

[1] Y. Sow, A. Thiam, B. Fall, M. Coulibali, A. Sarr, B. Diao et al. Cancer du pénis au Sénégal: aspects cliniques et thérapeutiques. Andrologie 2012; 22: 102-107.

[2] Gueye S. M., Diagne B. A, Ba M, Sylla C, Mensah A. Le cancer de la verge: aspects épidémiologiques et problèmes thérapeutiques au Sénégal. Med Afr Noire 1992; 39: 8-9.

[3] Figueiroa M N, Menezes M L N, Tavares L N, Maciel A F F, Gomes L. Profile of patients with penile neoplasms who have undergone penectomy. International Archive of Medecine 2017; 10: 223 .

[4] Magoha G A O, Ngumi Z W W. Cancer of the penis at Kenyatta National Hospital. East Afr Med J. 2000; 77: 526-30.
[5] Chalya PL, Rambau PF, Masalu N, Simbila S. Ten-year surgical experiences with penile cancer at a tertiary care hospital in northwestern Tanzania: a retrospective study of 236 patients. World Journal of Surgical Oncology 2015; 13: 71.

[6] Ficarra V, Mofferdine A, Malossini G, Mobilio G. Comparaison de la qualité de vie des patients traités pour cancer épidermoïde de la verge par chirurgie ou radiothérapie. Prog Urol 1999; 9: 715-720.

[7] Rozan R, Albuisson E, Giraud B, Boiteux J P, Dauplat J. Epithéliomas de la verge traités par chirurgie. Prog Urol 1996; 6: $926-935$.

[8] Luciano A F, Aguinaldo C N, Mario R, Stenio C. Z, Sampaio F J. B, Glina S. Epidemiologic Study on Penile Cancer in Brazil. International Braz J Urol 2008; 34 (5): 587-593.

[9] Sow M, Nkegoum B, Ama Moor VG, et al Les tumeurs du pénis au Cameroun: aspects épidémiologiques, cliniques, anatomo-pathologiques et thérapeutiques. Ann Pathol 2006; 26: 299-301.

[10] Maden C, Baruah IK. Carcinogenic action of human smegma. Arch Pathol 1963; 75: 414-420.

[11] Maden C, Sherman KJ, Beckman AM et al. History of circumcision, medical conditions, and sexual activity and risk of penile cancer. J Natl Cancer Inst 1993; 85: 19-24.

[12] Misra S, Chaturvedi A, Misra NC. Penile carcinoma: a challenge for the developing world. Lancet Oncol 2004; 5: 240-7.

[13] Cornu JN, Comparat E, Renard-Panna R, et al. Prise en charge carcinologique des cancers du pénis. Expérience d'un centre. Prog Urol 2007; 17: 1347-50.

[14] Burgers JK, Badalament RA, Drago JR. Penile cancer: clinical presentation, diagnosis, and staging. Urol Clin North Am 1992; 19: 247-256.

[15] Nam JK, Lee DH, Park SW, Kam SC et al. Clinicopathologic characteristics and treatment outcomes of penile cancer. Wold J Mens Health 2017; 35 (1): 28-33.

[16] Iborra F, Neuzillet Y, Méjean A, Lebret T. Métastase des cancers du pénis. Prog Urol 2008; 18 (Suppl 7): S 392-5.

[17] Rigaud J. Prise en charge des cancers du pénis. Prog Urol 2014; 13: 1238-42.

[18] Ornellas AA, Seixas AL, Marota A, Wisnescky A, Campos F, De Moraes JR. Surgical treatment of invasive squamous cell carcinoma of the penis: retrospective analysis of 350 cases. J Urol. 1994; 151: 1244-9.

[19] Leijte JA, Hughes B, Graafland NM, et al. Two-center evaluation of dynamic sentinel node biopsy for squamous cell carcinoma of the penis. J Clin Oncol 2009; 27: 3325-9.

[20] Sadeghi R, Gholami H, Zakavi SR, Kakhki VR, Tabasi KT, Horenblas S. Accuracy of sentinel lymph node biopsy for inguinal lymph node staging of penile squamous cell carcinoma: systematic review and meta- analysis of the literature. J Urol 2012; 187: 25-31. 